\title{
INHERITANCE OF GRAIN YIELD AND ITS COMPONENTS IN FOUR DURUM WHEAT CROSSES (TRITICUM DURUM L.)
}

\section{NADYA ADLY RIAD ABDEL-NOUR}

\author{
Wheat Research Department, Field Crops Research Institute, ARC, Egypt.
}

(Manuscript received 15 October 2010)

\begin{abstract}
Four experiments were carried out using the seven populations $\left(P_{1}, P_{2}, F_{1}, B C_{1}, B C_{2}, F_{2}\right.$ and $\left.F_{3}\right)$ method to study the genetic make up of four crosses namely: (1) Prico x Beni Swief 3, (2) Beni Swief 3 x Portoroco, (3) Quadrato x Beni Swief 1 and (4) Quadrato x Beni Swief 5 . Results indicated significant positive heterosis effects were found for all characters, except for 100-kernel weight $(\mathrm{g})$ in the first and second crosses. Significant positive heterosis were also evident for no. of kernels/spike and kernel weight in the third cross. On the other hand, significant negative heterotic effect was found all characters in the last cross and in no of spikes/plant and grain yield in the third one. Heterotic increase were also evident for no. of spikes/plant and no. of kernels/spike seemed to account for the heterotic yield response observed in the first and second crosses. Inbreeding depression was significant for grain yield in the all crosses, and no. of spikes/plant in the all crosses except the first cross, no. of kernels/spike in the second cross. 100- kernel weight (g) in the last cross. On the other hand significant negative inbreeding depression was also evident for no. of kernels/spike in the last cross. Over dominance towards the higher parent for all characters in the first and second cross except 100-kernel weight. However, partial dominance towards the higher parent was estimated for no. of spikes/plant in the fourth cross and 100-kernel weight in the first and second ones. Meanwhile, partial dominance towards the lower parent was estimated for grain yield in the third and fourth crosses, no. of spikes/plant in the third cross, and for no. of kernels /spike and 100-kernel weight in the last one. $F_{2}$ deviation $\left(E_{1}\right)$, backcross deviation $\left(E_{2}\right)$ and $F_{3}$ deviation $\left(E_{3}\right)$ were found to be significant for most of the characters under investigation. Moreover, high to moderate values of heritability estimates were found to be associated with moderate and low genetic advance as percentage of $F_{2}$ and $F_{3}$ means in most characters.

The additive gene effect (d) in six parameter model and in five parameters model were found to be significant for all characters in all crosses except for no. of spikes/plant and no. of kernels/spike in the second cross (Model 1). Suggesting the potential for obtaining improvements of most of the characters studied. Both dominance and epistais were found to be significant for most of the attributes under investigation. These obtained results indicated that selection for the studied characters could be used in the early generations but would be more effective if postponed to late ones.
\end{abstract}

Keywords: wheat, Crosses, Heterosis, Heritability, Inbreeding depression, Gene action. 


\section{INTRODUCTION}

The new Egyptian policy of wheat production is to increase the area cultivated by durum wheat in Upper Egypt because of its high tolerance to the prevalent hot weather. During the last decades, releasing new improved durum wheat cultivars has not release, other wheat objectives. Thereby local durum wheat cultivars of high yielding potentially and superior quality are now unavailable. Consequently, efforts to meet this shortage should be done as soon as possible.

The Egyptian wheat cultivars have relatively narrow genetic background. Selection among these cultivars for increasing grain yield and its components would not be very effective. Hybridization between the Egyptian wheat cultivars and exotic materials was carried out to increase genetic variability.

Genetic diversity among crossed parents enables the breeder to develop, through genetic recombination, heritable variability upon which selection can be practiced. Knowledge of genetic relationships among parents is essential for planning crosses that may lead to developing more promising lines. Crumpacker and Allard (1962) indicated that efficiency in breeding of self-pollinating crops depends, first, on accurate identification of hybrid combinations that have the potentially of production maximum improvements and second, on identifying in early segregating generations, superior lines among the progeny of the most promising hybrids. Therefore, information on the genetics of breeding materials could ensure selection gains and more genetic improvements.

Abul-Naas et al., (1991) reported that dominance played an important role in genetic control for number of spikes/plant, number of kernels/ spike, 100-kernek weight and grain yield/plant. On the other hand, El-Hosary et al., (2000), found that grain yield and its components in an eight durum wheat parents diallel cross, were controlled by both additive and non-additive gene effects. In addition concerning the heritability estimates, Hendawy (2003), Abdel-Nour, Nadya (2006), Abd-Allah (2007), Abd-Allah and Abdel-Dayem (2008) and Abdel-Nour, Nadya and Hassan (2009) reported that narrow sense heritability estimates for yield and its components were medium to high.

This work was conducted to study the gene action, heritability and actual and predicated genetic gains from selection in four durum wheat crosses derived from six diverse durum wheat genotypes using seven populations of each cross. 


\section{MATERIALS AND METHODS}

The four crosses used in the present study were derived from six widely diverse durum wheat cultivars. Names and pedigree of parental genotypes are given in Table (1). These genotypes were used to obtain the following four crosses: (1) Prico x Beni Swief 3, (2) Beni Swief 3 x Portoroco, (3) Quadrato x Beni Swief 1 and (4) Quadrato $x$ Beni Swief 5. Local cultivar Beni Swief 3 (have high yield and high number of kernels/spike) was crossed with exotic materials from Italy, both are good yielder and have high number of spikes/plant and heavy kernel weight. Cultivar Quadrato from Italy (good yielder and have high number of spikes/plant, high number of kernels/spike and heavy kernel weight) was crossed with the two local cultivars Beni Swief 1 and Beni Swief 5, both are good yielder, high number of spikes/ plant and heavy kernel weight.

The study was carried out at El-Giza Research Station during three successive seasons from 2006/2007 to 2008/2009. in 2009/2010 season, final experiment (the fourth season ) was conducted at Sids Research Station, Beni Swief Governorate, Agriculture Research Center, A.R.C.

In the first season (2006/2007), the parental genotypes were crosses to obtain $F_{1}$ seeds. In the second season (2007/2008), the hybrid seed of the four crosses were sown to give the $F_{1}$ plants. These plants were selfed to produce the $F_{2}$ seeds. Crossing was reported to ensure enough more fresh hybrid seeds. The new hybrid seed and part of the $F_{2}$ seeds were stored under refrigeration for further use. In the third season (2008/2009), $F_{1}, F_{2}$ and parents seed were sown to produce more $F_{2}$ seeds, back cross seed $\left(B_{1}\right.$ and $\left.\mathrm{BC}_{2}\right)$ by crossing each $F_{1}$ to their respective parent and $F_{2}$ plants were selfed to produce $F_{3}$ seeds.

In the fourth season $(2009 / 2010)$ the seven populations $\left(P_{1}, P_{2}, F_{1}, F_{2}, B C_{1}\right.$, $\mathrm{BC}_{2}, \mathrm{~F}_{2}$ and $\mathrm{F}_{3}$ of each of the four crosses were evaluated using a randomized complete block design with four replications. Rows were $4 \mathrm{~m}$ long spaced $20 \mathrm{~cm}$. apart. The plants within rows were $10 \mathrm{~cm}$. apart.

Table 1. The name, pedigree and origin of the six parental durum wheat cultivars :

\begin{tabular}{|c|l|c|}
\hline Genotype & \multicolumn{1}{|c|}{ Pedigree } & Origin \\
\hline Beni Swief 1 & $J^{\prime \prime} \mathrm{S}^{\prime} / \mathrm{AA}$ "S"// Fg "S" & Egypt \\
\hline Beni Swief 3 & Corm "S"/Ru fo "S" & Egypt \\
\hline Beni Swief 5 & Dipperz / Bushen3 & Egypt \\
\hline Prico & & Italy \\
\hline Portoroco & & Italy \\
\hline Quadrato & & Italy \\
\hline
\end{tabular}


Plot consisted of two rows for each parents, $F_{1}$ and backcross, five rows for $F_{2}$ generation and 20 rows for $F_{3}$ families selected from $F_{2}$ at season 2008/2009 from each cross. Data were recorded on individual guarded plants from each plot (50 plants from $F_{2}, 40$ plants from bulk $F_{3}, 40$ plants from each back crosses and 10 plants for parents and $F_{1}$ ) for number of spikes/plant, number of kernels/spike, 100-kernel weight $(\mathrm{g})$ and grain yield/plant $(\mathrm{g})$.

The amount of heterosis was expressed as the percentage increase of $F_{1}$ above mid parents and better parent values. Inbreeding depression was calculated as the difference between the $F_{1}$ and $F_{2}$ means expressed as percentage of the $F_{1}$ mean, and the difference between the $F_{2}$ and $F_{3}$ means expressed as percentage of the $F_{2}$ mean .

The T-test was used to determine the significance of these deviations where the standard error (S.E) was calculated as follows:

\section{S.E for mid parents heterosis}

$$
F_{1}-1 / 2\left(P_{1}+P_{2}\right)=\left[V F_{1}+1 / 4\left(V P_{1}+V P_{2}\right)\right]^{1 / 2}
$$

S.E. for better parent heterosis :

$$
\left.\overline{F_{1}}-\overline{B P}=\overline{\left(V_{1}\right.}+\overline{V B P}\right)^{1 / 2}
$$

\section{And S.E for inbreeding depression:}

$$
\begin{aligned}
& \overline{F_{1}}-\overline{F_{2}}=\left(\overline{V F_{1}}+\overline{V F_{2}}\right)^{1 / 2} \\
& \left.\overline{F_{2}}-\overline{F_{3}}=\overline{\left(V F_{2}\right.}+\overline{V F_{3}}\right)^{1 / 2}
\end{aligned}
$$

In addition $F_{2}$ deviation $\left(E_{1}\right)$, backcross deviation $\left(E_{2}\right)$ and $F_{3}$ deviation $\left(E_{3}\right)$ were measured as suggested by Mather and Jinks (1971). Potence ratio (P) was also calculated according to Peter and Frey (1966).

Type of gene effects was estimated according to Gamble (1962) six parameters model as follows:

The standard error of additive (a), dominance (d), additive $\mathrm{x}$ additive (aa), additive $\mathrm{x}$ dominance (ad) and dominance $x$ dominance ( $\mathrm{dd}$ ) were obtained by taking the squares root of respective variation " $\mathrm{T}$ " test values are calculated upon dividing the effect of $a, d, a a$, ad and dd by their respective standard error.

$$
\begin{aligned}
\mathrm{m} & =\overline{\mathrm{F}_{2}} \\
\mathrm{a} & =\overline{\mathrm{BC}_{1}}-\overline{\mathrm{BC}_{2}} \\
\mathrm{~d} & =\overline{\mathrm{F}_{1}}-\overline{4 \mathrm{~F}_{2}}-\overline{1 / 2 \mathrm{P}_{1}}-\overline{1 / 2} \mathrm{P}_{2}+\overline{2 \mathrm{BC}} \mathrm{C}_{1}+\overline{2 \mathrm{BC}_{2}} \\
\mathrm{a} & =\overline{2 \mathrm{BC}_{1}}+\overline{2 \mathrm{BC}} 2-\overline{4 \mathrm{~F}_{2}} \\
\mathrm{ad} & =\overline{\mathrm{BC}_{1}}-\overline{1 / 2 \mathrm{P}_{1}}-\overline{\mathrm{BC}_{2}}+\overline{1 / 2} \mathrm{P}_{2} \\
\mathrm{dd} & =\overline{\mathrm{P}_{1}}+\overline{\mathrm{P}_{2}}-\overline{4 \mathrm{~F}_{1}}+\overline{4 \mathrm{~F}_{2}}-\overline{4 \mathrm{BC}_{2}}
\end{aligned}
$$


The variances of these estimates were computed as follow:

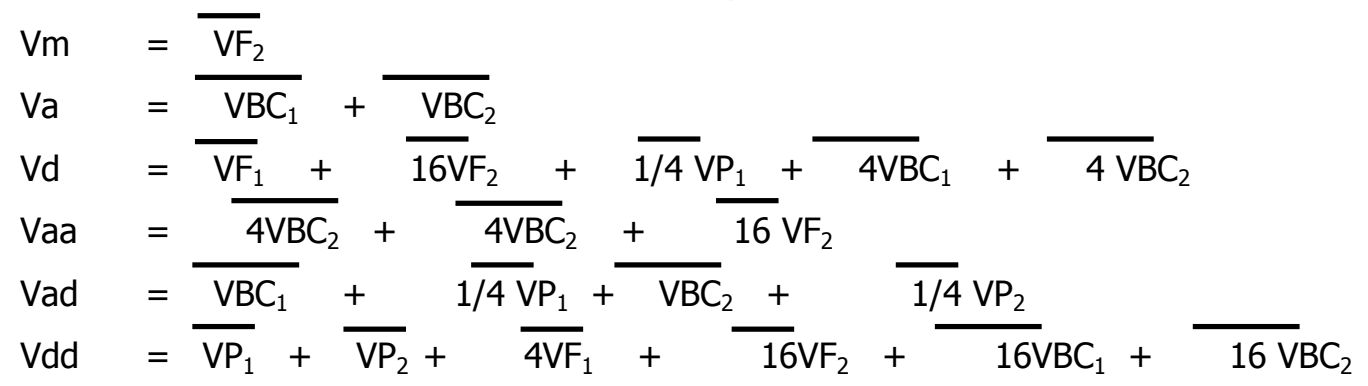

And also type of gene effects was estimated according to Singh and Chaudhery (1985) five parameters model as follow:

The standard error of additive (a), dominance (d), additive $x$ additive (aa), and dominance $x$ dominance $(\mathrm{dd})$ were obtained by taking the squares root of respective variation " $T$ " test values are calculated upon dividing the effects of $a, d$, aa, and dd by their respective standard error.

$$
\begin{aligned}
\mathrm{m} & =\overline{\mathrm{F}_{2}} \\
\mathrm{a} & =\overline{1 / 2 \mathrm{P}_{1}}-\overline{1 / 2 \mathrm{P}_{2}} \\
\mathrm{~d} & \left.=1 / 6 \overline{\left(4 \mathrm{~F}_{1}\right.}+\overline{12 \mathrm{~F}_{2}}-\overline{16 \mathrm{~F}_{3}}\right) \\
\mathrm{dd} & \left.=1 / 3 \overline{\left(16 \mathrm{~F}_{3}\right.}-\overline{24 \mathrm{~F}_{2}}+\frac{\left.8 \mathrm{~F}_{1}\right)}{\mathrm{P}_{1}}+\mathrm{d}\right)-1 / 4 \mathrm{dd}
\end{aligned}
$$

and

$$
\begin{aligned}
\mathrm{Vm} & =\overline{\mathrm{VF}_{2}} \\
\mathrm{Va} & =1 / 4\left(\overline{\mathrm{VP}_{1}}+\overline{\mathrm{VP}_{2}}\right) \\
\mathrm{Vd} & =1 / 36\left(\overline{16} \overline{\mathrm{VF}_{1}}+1 \overline{44 \mathrm{VF}_{2}}+25 \overline{\mathrm{VF}_{3}}\right) \\
\mathrm{Vdd} & =1 / 9\left(256 \overline{\mathrm{VF}}_{3}+576 \overline{\mathrm{VF}}_{2}+6 \overline{4 \mathrm{VF}_{1}}\right) \\
\mathrm{Vaa} & =\overline{\mathrm{VP}_{1}}+\overline{\mathrm{VF}_{2}}+1 / 4\left(\mathrm{VP}_{1}+\overline{\mathrm{VP}}_{2}+\mathrm{Vd}\right)+1 / 16 \mathrm{Vdd}
\end{aligned}
$$

Heritability in broad and narrow sense was calculated according to Mather (1949) and parent off-spring regression according to Sakai (1960). Furthermore, the predicated and actual genetic advance $(\Delta \mathrm{g})$ from selection were computed according to Johnson et al., (1955).

The genetic gain as percentage of the $F_{2}$ and $F_{3}$ mean performance $(\Delta g \%)$ was computed using the method of Miller et al., (1958).

\section{RESULTS AND DISCUSSION}

Varietals differences were significant in most characters under investigation. The $F_{2}$ genetic variances were also significant for all studied characters in the four crosses. Therefore, the different biometrical parameters used in this investigation were 
estimated. Means and variances of the seven populations $\left(\mathrm{P}_{1}, \mathrm{P}_{2}, \mathrm{~F}_{1}, \mathrm{BC}_{1}, \mathrm{BC}_{2}, \mathrm{~F}_{2}\right.$ and $F_{3}$ ) for the characters studied in the four crosses are presented in Table (2). Heterosis relative to both mid parents and better parent, inbreeding depression percentage, potence ratio (p), $E_{1}, E_{2}, E_{3}$ and heritability estimates in each cross for the four studied characters are given in Table (3).

Significant positive heterosis was found for all characters except kernel weight in the first and the second crosses, No. of kernels/spike and kernel weight in the third cross. Significant negative heterosis was found for No. of spikes/plant and grain yield/plant in the third cross, all characters except kernel weight in the first and the second crosses, no. of kernels/spike and kernel weight in the third cross. Significant negative heterosis was found for no. of spikes/plant and grain yield/plant in the third cross, all characters in the fourth cross except no. of spikes/plant alone positive heterosis over mid parents in this cross. Similar results were reported by El-Hosary et al., (2000), Hendawy (2003), Abdel-Nour, Nadya (2006) and Abdel-Nour, Nadya and Hassan (2009).

Number of spikes/plant, number of kernels/spike and kernel weight are the main components of grain yield/plant. Hence, heterotic increase if found in one or more of these attributes with others attributes being constant would lead to favourable yield increase in hybrids. The lack of significant in heterosis of kernel weight in the first and second ones could be due to the lower magnitude of the nonadditive gene action. These results are in agreement with Amaya et al., (1972).

The pronounced heterotic effect detected in number of spikes/plant and numder of kernels/spike in the first and the second crosses would be of interested in a breeding program for high yielding ability.

The potence ratio indicated over-dominance towards the higher parent for all characters except for kernel weight in the first and second crosses, number of kernels/spike and kernel weight in the third one. There were partial dominance towards the higher parent for number of spikes/plant in the fourth one. Meanwhile, partial dominance towards the lower parent was found for number of spikes/plant and grain yield/plant in the third cross, and for all characters except number of spikes/plant in the fourth one. These results are in harmony with those obtained by Abul-Naas et al., (1991), Hendawy (2003), Abdel-Nour, Nadya (2006), Abd-Allah and Abdel-Dayem (2008) and Abdel-Nour, Nadya and Hassan (2009).

Significant inbreeding depression was found for all characters except number of kernels/spike in the fourth cross, number of spikes/plant and grain yield/plant in the second and the third crosses and grain yield/plant in the first one. However, significant negative inbreeding depression (inbreeding gain) was detected for number of 
kernels/spike in the fourth cross. This is valid result, since the expression of heterosis in $F_{1}$ may be followed by considerable reduction in $F_{2}$ performance. The obtained results for most cases were in harmony with those obtained by Abdel-Nour, Nadya (2006) and Abdel-Nour Nadya and Hassan (2009).

Significant heterosis and insignificant inbreeding depression were obtained for all characters except grain yield/plant in the first cross, number of kernels /spike and kernel weight in the third cross were detected. The contradiction between heterosis and inbreeding depression estimates could be due to the presence of linkage between genes in these materials (Van der Veen 1959). Significant positive $F_{2}$ deviation $\left(E_{1}\right)$ were indicated for number of spikes/plant in the first cross, for number of kernels /spike in the first and third ones. Meanwhile, significant negative values were obtained for number of spikes/plant and grain yield/plant in the third cross, for kernel weight and grain yield/plant in the fourth one. These results may be refer to the contribution of epistatic gene effects in the performance of these characters.

On the other hand, insignificant $F_{2}$ deviations were detected for all characters except for number of kernels/spike in the first cross, for all characters except for number of spikes/plant in the second cross, for kernel weight in the third cross and for number of kernels/spike in the fourth one. This may indicated that the epistatic gene effects have minor contribution in the inheritance of these characters.

Backcrosses deviations $\left(E_{2}\right)$ was significant for all characters in all crosses except for number of spikes/plant in the fourth cross, for number of kernels/spike in the first and the third crosses and for grain yield/plant in the third one. 
Table 2 
Table 3 
Also $F_{3}$ deviation $\left(E_{3}\right)$ was significant for all characters except for kernel weight in the first and third crosses, for no. of kernels/spike in the second and third crosses and for number of spikes/plant and grain yield/plant in the second one. These results would ascertain the presence of epitasis in such large magnitude as to warrant great deal of attention in breeding programs.

Heritability in both broad and narrow senses and between generations (parent-offspring regression) are presented in Table (3). High heritability values in broad sense were detected for all studied characters indicating that superior genotypes for these characters could be identified from the phenotypic expression and illustrate the importance of straight forward phenotypic selection for improvement of these traits except for number of kernels/spike in the second cross and for kernels weight in all crosses except in the fourth cross where moderate broad sense heritability estimates were detected. High to moderate estimates of narrow sense heritability and between generations was found for all studied characters in all crosses. The differences in magnitude of both broad and narrow sense and parentoffspring regression heritability estimates for all studied characters would ascertained the presence of both additive and non-additive gene effects in the inheritance of these characters. This conclusion was also confirmed by estimates of gene action parameter. Similar results were obtained by Abdel-Nour, Nadya (2006), Abdel-Allah and AbdelDayem (2008) and Abdel-Nour, Nadya and Hassan (2009).

Table (4) shows the predicted versus actual gain for all studied characters. The actual genetic advance (actual gain $\Delta \mathrm{g} \%$ ) regard from low to moderate for all studied characters in all crosses. These results indicated the possibility of practicing selection in early segregation generation to enhance these characters and hence selecting high yielding genotypes. Dixit et al., (1970) pointed out that high heritability is not always associated with high genetic advance, but in order to make effective selection, high heritability should be associated with high genetic gain.

Nature of gene action was determined according to Gamble (1962) six parameters model (Table 5$)$. The estimated mean effect parameter $(m)$, which reflects the contribution due to the over all mean plus the locus effect and interactions of the fixed loci, was found to be highly significant. The additive gene (a) was significantly positive for all characters except for kernel weight in the first cross and for all characters except for number of kernels/spike in the third and fourth crosses. These results suggest the potential for obtaining further improvement for these characters by using pedigree selection program. Similar results were obtained by Amaya et al., (1972), El-Hosary et al., ( 2000 ), Abdel-Nour, Nadya (2006), Abdel-Allah and Abdel-Dayem (2008) and Abdel-Nour, Nadya and Hssan (2009). On the other hand 
Table 4. predicated and actual gain from selection for all characters in four durum wheat crosses.

\begin{tabular}{|c|c|c|c|c|c|}
\hline \multirow{2}{*}{ Characters } & \multirow{2}{*}{ cross } & \multicolumn{2}{|c|}{ Predication gain } & \multicolumn{2}{|c|}{ Actual gain } \\
\hline & & $\mathbf{g}$ & $\%$ of $F_{2}$ & $\mathbf{g}$ & $\%$ of $F_{3}$ \\
\hline \multirow{4}{*}{$\begin{array}{c}\text { No. of } \\
\text { Spikes / plant }\end{array}$} & 1 & 11.20 & 64.37 & 10.36 & 63.94 \\
\hline & 2 & 11.456 & 53.66 & 12.347 & 57.99 \\
\hline & 3 & 10.13 & 63.20 & 10.40 & 72.37 \\
\hline & 4 & 7.081 & 40.21 & 7.854 & 45.17 \\
\hline \multirow{4}{*}{$\begin{array}{c}\text { No. of } \\
\text { kernels / plant }\end{array}$} & 1 & 19.76 & 33.41 & 20.84 & 35.61 \\
\hline & 2 & 10.779 & 17.11 & 11.339 & 18.32 \\
\hline & 3 & 12.158 & 17.22 & 12.61 & 18.22 \\
\hline & 4 & 12.47 & 21.86 & 12.45 & 20.45 \\
\hline \multirow{4}{*}{$\begin{array}{c}\text { 100- kernel weight } \\
\text { (g) }\end{array}$} & 1 & 0.642 & 12.26 & 0.703 & 13.61 \\
\hline & 2 & 0.697 & 13.64 & 0.702 & 14.08 \\
\hline & 3 & 0.791 & 14.08 & 0.733 & 13.33 \\
\hline & 4 & 0.953 & 17.38 & 0.882 & 16.96 \\
\hline \multirow{4}{*}{$\begin{array}{c}\text { Grain yield / plant } \\
\text { (g) }\end{array}$} & 1 & 18.014 & 37.22 & 17.64 & 38.52 \\
\hline & 2 & 22.658 & 43.58 & 20.802 & 41.678 \\
\hline & 3 & 16.58 & 33.77 & 15.20 & 31.27 \\
\hline & 4 & 23.06 & 46.62 & 22.14 & 45.43 \\
\hline
\end{tabular}


significant negative additive effect (a) was obtained for kernel weight in the first cross, for kernel weight and grain yield/plant in the second cross and for number of kernels/spike in the third and fourth crosses. Dominance gene effect (d) was significant for kernel weight in the first and third crosses, for all characters in the second cross and for all characters except for grain yield/plant in the fourth one.

The significant of these components indicated that both additive and dominance gene effects are important in the inheritance of these characters. Therefore, selecting desired characters could be practiced in the early generations but would be more effective in late ones.

When dominance gene are present, it would tend to favor the production of hybrid, while the existence of the additive gene action in the gene pool encourage the improvement of the character by selection program.

Additive $\mathrm{x}$ additive type of epistasis (aa) was detected to be significant for all characters except for number of spikes/plant in the first and third crosses, for all characters except for grain yield/plant in the second cross and for all characters except for grain yield/plant in the fourth one.

Significant additive $\mathrm{x}$ dominance (ad) appeared for number of kernels/spike in all crosses, for number of spikes/plant in the first cross, for kernels weight in all crosses except in the second cross and for grain yield/plant in the fourth cross. Dominance $\mathrm{x}$ dominance (dd) type of gene action was significant for all characters except for number of kernels/spike in the first cross, for all characters except for grain yield/plant in the second and third crosses and for number of kernels/spike and kernel weight in the fourth one. These results confirm the importance role of dominance $x$ dominance gene interactions in the genetic system controlling these characters.

Nature of gene action investigated using the five parameters analysis (Hyman's model) according to Singh and Chaudhary (1985) was presented in Table (5). The estimated mean effect parameter $(m)$, which reflects the contribution due to the over all mean plus the locus effect and interactions of the fixed loci, was highly significant. The parameter (a) was significantly positive for number of spikes/plant in all crosses, for number of kernels / spike in the fourth cross, for kernel weight in the first and third crosses and for grain yield /plant in all crosses except the second cross.

Meanwhile, (a) was significantly negative for number of kernel/spike in all crosses except the fourth cross, for kernel weight in the second and the fourth crosses and for grain yield/plant in the second one. The dominance effect (d) was significant for number of spikes/plant in the first and the third crosses, for number of kernels/spike and kernel weight in all crosses except the first cross and for grain yield/ plant in the first and the second ones, indicating the importance of dominance gene 
effects in the inheritance of all characters. Meanwhile, additive $x$ additive (aa) was significant for all characters in all crosses except for number of spikes/plant in the second cross, number of kernels/spike in the fourth cross, kernel weight in the second and the third crosses. Moreover, dominance $\mathrm{x}$ dominance (dd) was significant for number of kernels/spike and kernel weight in the fourth one.

The important roles of both additive and non-additive gene action in most studied characters indicated that selection procedures based on the accumulation of additive effects would be very successful in improving these characters. Similar results were reported by Abdel-Nour, Nadya (2006), El-Hosary et al., (2000), Abdel-Allah and Abdel-Dayem (2008) and Abdel-Nour, Nadya and Hassan (2009).

Generally, the most biometrical parameters resulted from these crosses were higher in magnitude. Consequently, it could be concluded that the crosses (Prico $x$ Beni Swief 3), (Beni Swief 3 x Portoroco), (Quardrato x Beni Swief 1) and (Quardrato $x$ Beni Swief 5) would be interest in a breeding program for brining about the maximum genetic improvement and selection for the studied characters could be used in the early generations but would be more effective if postponed to late ones. 
TABLE 5 


\section{REFERENCES}

1. Abdel-Allah, Soheir M. H and S. M. A Abdel-Dayem. 2008. Determination of gene effects and variances in three wheat crosses. Ann. Agri. Sci. Moshtohor. 46(1): Ag. 23-31.

2. Abdel-Nour, A. R. Nadya. 2006. Genetic variation in grain yield and its components in three bread wheat crosses. Egypt J. Plant Breed. 10 (1): $289-304$.

3. Abdel-Nour, Nadya A. R and M. A. Hassam. 2009. Determination of gene effects and variance in three bread wheat crosses for low water (drought). Egypt J. Plant Breed. 13: 235 - 249.

4. Abul-Naas, A. A., A. A. El-Hosary and M. Asaker. 1991. Genetical studies on durum wheat (Triticum durum L.) Egypt. J. Agron. 16 (1-2): 81 - 94.

5. Amaya, A. A., R. H. Busch and K. L. Lebsock. 1972. Estimates of genetic effects of heading date, plant height and grain yield in durum wheat Crop Sci. 12: 478 481.

6. Crumpacker, D. W and R. W. Allard. 1962. A diallel cross analysis of heading date wheat Hilgardi, 32: $275-277$.

7. Dixit, P. K., P. D. Saxena and L. K. Bhatia. 1970. Estimation of genotypic variability of some quantitative characters in groundnut. Indian J. Agric. Sci. 40: $197-201$.

8. El-Hosary, A.A., M. E. Riad, Nagwa A. Rady and Manal A. Hassan. 2000. Heterosis and combining ability in durum wheat Proc. $9^{\text {th }}$ Conf. Agron., Minufiya Univ., Sep.: $101-117$.

9. Gambl, E.E. 1962. Gene effects in corn (Zea mays L.). Separation and relative importance of gene effects for yield. Canadian J. of plant Sci. 42: 339 - 348.

10. Johanson, H. W., H. F. Robinson and R. E. Comstock. 1955. Estimates of genetic and environmental variability of soybeans. Agron. J. 47: 314.

11. Mather, K. 1949. Biometrical Genetics. Methuen Co., Ltd. London.

12. Mather, K. and J. L. Jinks. 1971. Biometrical Genetics. $2^{\text {nd }}$ edition. Champman and Hill Ltd, London.

13. Miller, P. A., J. C. Williams, H. F. Robinson, and R. E. Comstock. 1958. Estimates of genotypes and environmental variances in upland cotton and their implications in selection Agron. J. 50: 126 - 131.

14. Peter, F. C and K. J. Frey. 1966. Genotypic correlation, dominance and heritability of quantitative characters in Oats. Crop. Sci. 6: $259-262$.

15. Sakai, K. I. 1960. Scientific basic of plant breeding lectures given at the Fac. of Agri. Cairo Univ. and Alex. Univ.

16. Singh, R. R. and B. D. Chaudhary. 1985. Biometrical Methods in Quantitative Genetic Analysis. Kalyani Publisher New Delhi, Ludhiana, India.

17. Van der Veen, J. H. 1959. Test of non-allelic interaction and linkage for quantitative characters in generation derived from two diploid pure lines. Genetica 30: 201. 


\section{توارث محصول الحبوب ومكوناته في أريع هجن من قمح الديورم}

\section{نادية علدي رياض عبد النور}

$$
\text { قسم بحوث القهح - معهز الدحاصيل الحقلية - مركز البحوث الزراعية - الجبية }
$$

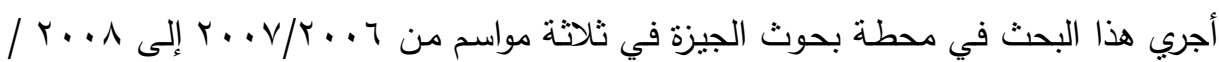

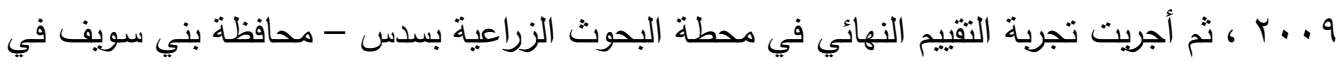

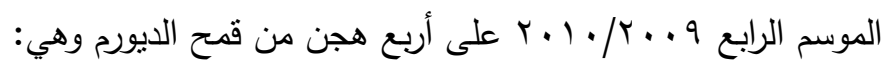

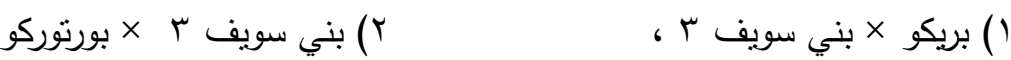

$$
\begin{aligned}
& \text { r) كوادرتو × بني سويف ل }
\end{aligned}
$$

واشتملت الدراسة على كل من الأبوين والجيل الأول والجيلين الرجعيين والجيلين الثاني والثالث

$$
\text { ، وكانت النتائج كما يلي }
$$

ا- كانت قوة الهجين في الجيل الأول بالنسبة لمنوسط الأبوين وللأب الأفضل معنوية وموجبة

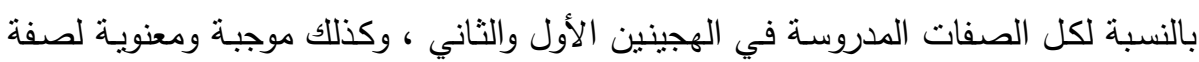

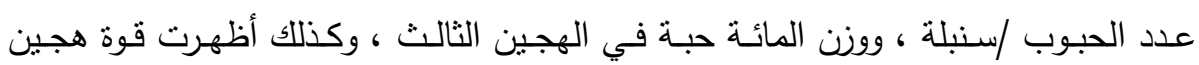
بالنسبة لصفة عدد السنابل / نبات في الهجين الرابع •

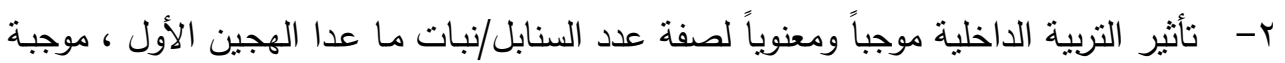

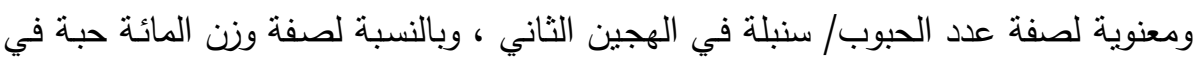

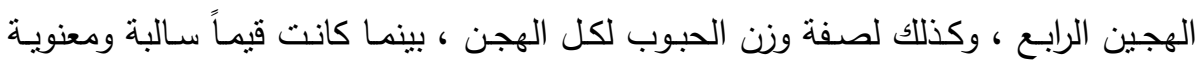

$$
\text { لصفة عدد الحبوب/سنبلة في الهجين الرابع. }
$$

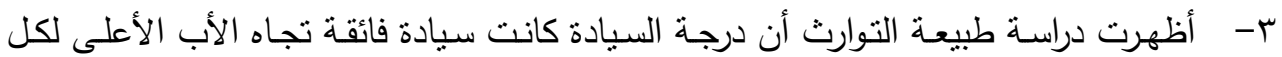

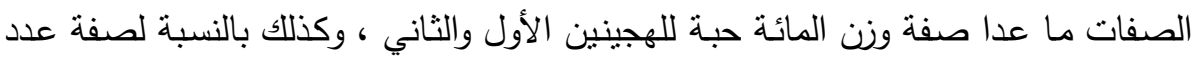
الحبوب /سنبلة ، ووزن المائة حبة في الهجين الثالث ـ وكذلك أمكن تحديد سبادة جزئية نحو الأب الأعلى لصفة عدد السنابل/نبات في الهجين الرابع ، وصفة وزن المائة حبة للهجينين

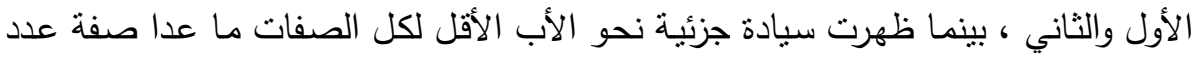

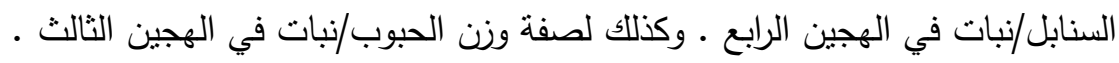

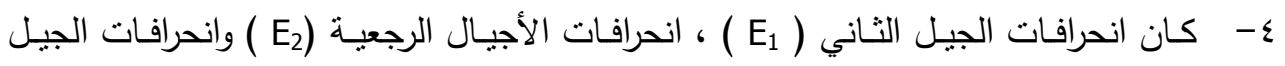

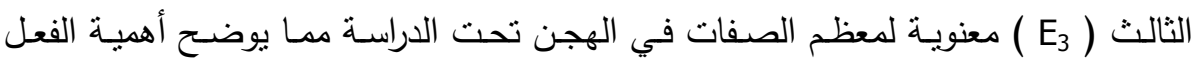

$$
\text { الجيني التفوقي في وراثة هذه الصفات. }
$$

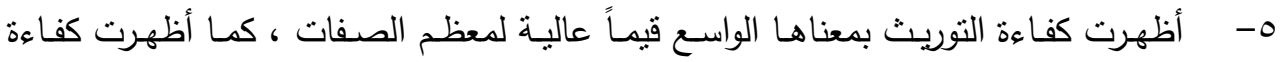

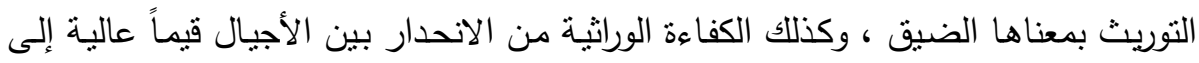

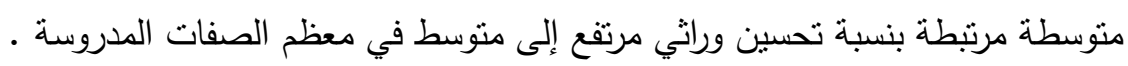


צ- كانت قيمة التحسين الوراثي الفعلي المتحصل عليها بصفة عامـة متطابقة مع القيمة المنتبأ

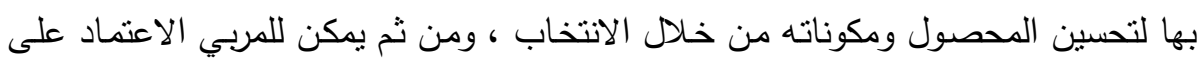

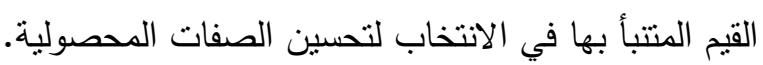
- - أظهرت النأثيرات الوراثية المضيفة وكذلك الفعل الجيني غير المضيف دوراً هاماً في وراثة معظم الصفات المدروسة . معزت 1- يمكن الاستفادة من الهجن الأربعة في برامج تربيـة القـح للحصول على سـلالات جديدة

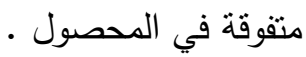
9- النتائج المتحصل عليهـا تدل على أن الانتخـاب في الأجيال الانعزاليـة المبكرة قد يكون

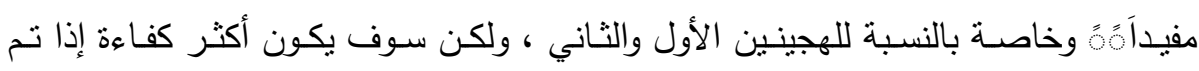

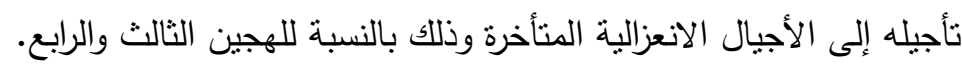

